\title{
Effect of intraruminal infusion of potassium on the site of magnesium absorption within the digestive tract in sheep
}

\author{
D. E. DALLEY ${ }^{1 *}$, P. ISHERWOOD ${ }^{1}$, A. R. SYKES ${ }^{1}$ AND A. B. ROBSON ${ }^{2} \dagger$ \\ ${ }^{1}$ Animal and Veterinary Sciences Group, Lincoln University, Canterbury, New Zealand \\ ${ }^{2}$ Centre for Computing and Biometrics, Lincoln University, Canterbury, New Zealand
}

(Revised MS received 12 November 1996)

\begin{abstract}
SUMMAR Y
Sixteen 2-year old female sheep were fitted with ruminal and duodenal cannulae at Johnstone Memorial Laboratory, Lincoln University during 1989-90. They were offered, at 2 hourly intervals, a pelleted concentrate diet ( $900 \mathrm{~g} /$ day) and chaffed lucerne hay (100 g/day). In a split-plot experiment they were infused, intraruminally and at four rates, with potassium (providing 16, 26, 36 or $46 \mathrm{~g} \mathrm{~K} / \mathrm{kg}$ food DM/day) and magnesium (providing $1 \cdot 3,1 \cdot 8,2 \cdot 3$ or $3 \cdot 1 \mathrm{~g} \mathrm{Mg} / \mathrm{kg}$ food DM/day) within a Latin square design and with the liquid and solid phase markers ${ }^{51}$ chromium EDTA and ${ }^{141}$ cerium chloride. Net absorption of $\mathrm{Mg}$ before and after the duodenum was estimated from dietary intake, duodenal flow and urinary and faecal excretion of $\mathrm{Mg}$.

Increasing $\mathrm{K}$ intake resulted in a decline in net absorption of $\mathrm{Mg}$ from the entire digestive tract, supporting data in the literature. Increasing $\mathrm{K}$ intake from 16 to $46 \mathrm{~g} / \mathrm{kg} \mathrm{DM}$ decreased urinary $\mathrm{Mg}$ excretion by between $0 \cdot 14$ and $0.30 \mathrm{~g} /$ day, the extent of which was independent of the level of $\mathrm{Mg}$ intake. At high $\mathrm{K}$ intake $\mathrm{Mg}$ absorption from the rumen was reduced, the amount absorbed ranging from $0.07 \mathrm{~g} \mathrm{Mg} /$ day at intakes of $1.3 \mathrm{~g} \mathrm{Mg}$ /day and $46 \mathrm{~g} \mathrm{~K} / \mathrm{kg} \mathrm{DM} /$ day to $0.66 \mathrm{~g} \mathrm{Mg} /$ day at intakes of $3.1 \mathrm{~g} \mathrm{Mg} /$ day and $16 \mathrm{~g} \mathrm{~K} / \mathrm{kg} \mathrm{DM} /$ day. However, at high $\mathrm{K}$ intake, and when $\mathrm{Mg}$ absorption from the rumen was reduced, net $\mathrm{Mg}$ absorption from sites distal to the rumen was increased to an extent which suggested compensatory absorption. Increase in $\mathrm{K}$ intake was associated with a consistent reduction in plasma $\mathrm{Mg}$ concentration which was independent of $\mathrm{Mg}$ intake. Increases in $\mathrm{Mg}$ intake resulted in increases in $\mathrm{Mg}$ absorption and plasma $\mathrm{Mg}$ concentration at all rates of $\mathrm{K}$ intake in direct proportion to rate of intake. The reduction in $\mathrm{Mg}$ absorption from the rumen at high $\mathrm{K}$ intake was associated with an increase $(0 \cdot 3$ units $)$ in $\mathrm{pH}$ of rumen digesta.
\end{abstract}

\section{INTRODUCTION}

It is well established that dietary potassium $(\mathrm{K})$ decreases magnesium $(\mathrm{Mg})$ absorption in ruminants (Newton et al. 1972; Tomas \& Potter 1976a; Field \& Suttle 1979; Greene et al. $1983 a, b, c$; Martens \& Blume 1986). Quantitative data showing the response surfaces of $\mathrm{Mg}$ absorption to changes in dietary $\mathrm{Mg}$ and $\mathrm{K}$ encountered under grazing conditions, suitable for incorporation into a simulation model of $\mathrm{Mg}$ metabolism (Robson 1991) are not, however, available.

Little is known about the effects of high $\mathrm{K}$ intake on the partitioning of net $\mathrm{Mg}$ absorption between

\footnotetext{
* Present address: Agriculture Victoria, Ellinbank, RMD 2460, Warragul, Victoria, 3820, Australia

$\dagger$ To whom correspondence should be addressed.
}

sites in the gastrointestinal tract. The rumen is considered to be the major site of $\mathrm{Mg}$ absorption (Tomas \& Potter 1976a,b; Field \& Munro 1977; Gabel \& Martens 1985) but there is evidence that absorption can also occur from the large intestine (Grace \& MacRae 1972; Ben-Ghedalia et al. 1975; Tomas \& Potter 1976b; Dalley \& Sykes 1989). The role of the large intestine in $\mathrm{Mg}$ homoeostasis, particularly under conditions of depressed ruminal $\mathrm{Mg}$ absorption, is not clear.

This trial was designed first to study the interactions between dietary $\mathrm{Mg}$ and $\mathrm{K}$ within the range of concentrations encountered in forages and second to measure the partitioning of absorption between the rumen and post-ruminal sites. A further objective was to establish whether increasing $\mathrm{Mg}$ intake would overcome the depression in $\mathrm{Mg}$ absorption that occurs at high $\mathrm{K}$ intake. 


\section{MATERIALS AND METHODS}

Sixteen 2-year-old female Coopworth sheep, average liveweight $43 \pm 3 \mathrm{~kg}$, were fitted with a rigid permanent cannula ( $3 \mathrm{~cm}$ i.d.) in the rumen and a T-shaped cannula in the proximal duodenum (c. 50-100 $\mathrm{mm}$ distal to the pylorus), at least 2 months prior to experimentation. This surgery was carried out at the Johnstone Memorial Laboratory, Lincoln University during 1989-90. Normal cannulation techniques were used (Hecker 1974).

Animals were housed indoors in metabolism crates designed for the separation and collection of urine and faeces. They were offered $900 \mathrm{~g} /$ day of a pelleted diet based on barley grain, barley malt culms and barley straw with a trace element premix and $100 \mathrm{~g} /$ day of chaffed lucerne (Medicago sativa) hay, both of which were delivered at $2 \mathrm{~h}$ intervals, and had free access to fresh tap water.

Animals, ranked hierarchically by weight, were allocated to one of $4 \mathrm{~K}$ treatment groups, $0,8 \cdot 9$, $17 \cdot 8$ and $26.7 \mathrm{~g} \mathrm{~K} /$ day for $\mathrm{K}$ treatments $1-4$, respectively. Within each $\mathrm{K}$ treatment four rates of $\mathrm{Mg}$ infusion, 0 , $0 \cdot 5,1$ and $2 \mathrm{~g} /$ day, were randomly allocated within a Latin square design.

The $\mathrm{K}$ and $\mathrm{Mg}$ supplements, provided as aqueous solutions of chloride salts, were infused into the rumen through polyvinyl chloride tubing at a rate of $460 \mathrm{ml} /$ day during 12-day periods. Sodium bicarbonate was infused into the rumen, independently of $\mathrm{K}$ and $\mathrm{Mg}$, to deliver $0.8 \mathrm{~g} \mathrm{Na} /$ animal/day in $144 \mathrm{ml}$ water. This was done to protect animals from $\mathrm{Na}$ deficiency at high $\mathrm{K}$ infusion rates, a situation which occurred in a preliminary trial.

Digesta flow past the duodenal cannula was calculated according to the double marker technique of Faichney (1975) using the ${ }^{51}$ chromium $\left({ }^{51} \mathrm{Cr}\right)$ complex of ethylenediaminetetraacetic acid $\left({ }^{51} \mathrm{Cr}\right.$ EDTA; Downes \& McDonald 1964) and ${ }^{141} \mathrm{Ce}$ (cerium chloride in $0 \cdot 1 \mathrm{~m}$ hydrochloric acid $(\mathrm{HCl})$ ) as liquid and solid phase markers, respectively. Approximately $40 \mu \mathrm{Ci}{ }^{51} \mathrm{Cr}$ EDTA and $8 \mu \mathrm{Ci}{ }^{141} \mathrm{Ce}$ were included in the sodium bicarbonate solution during the final 8 days of each infusion period. Samples $(50 \mathrm{ml})$ of duodenal digesta were collected at 4-h intervals and rumen fluid $(200 \mathrm{ml})$ at 8 -h intervals during the last 4 days of the infusion period and stored at $4{ }^{\circ} \mathrm{C}$.

Feed offered and refusals were recorded and subsampled daily. Faeces and urine were collected and measured daily throughout the 12-day infusion period. Urine was acidified to $\mathrm{pH} \mathrm{2-3}$ with $1 \mathrm{M} \mathrm{HCl}$ and the faeces homogenized before each were subsampled and stored at $-20^{\circ} \mathrm{C}$. At $08.30 \mathrm{~h}$ throughout the infusion period, $5 \mathrm{ml}$ jugular blood was withdrawn through an indwelling jugular catheter, transferred to blood tubes containing lithium heparin (72 USP units), centrifuged at $1200 \mathrm{~g}$ for $15 \mathrm{~min}$ and the plasma stored at $-20{ }^{\circ} \mathrm{C}$.

\section{Laboratory analysis}

Samples of rumen and duodenal digesta were centrifuged at $30000 \mathrm{~g}$ for $30 \mathrm{~min}$ and the supernatant removed. Further aliquots $(10 \mathrm{ml})$ of rumen and duodenal digesta were suspended in agar $(0.5 \mathrm{~g})$ in counting tubes by heating, taking care to maintain a uniform suspension, until the agar set. Radioactivity in both the whole digesta and supernatant fractions was counted in a universal gamma counter (1282 Compugamma, LKB, Wallac).

Feed, faeces and digesta samples were dried to constant weight at $100^{\circ} \mathrm{C}$. Feed and faeces samples were wet-ashed by the technique of Thompson \& Blanchflower (1971). Rumen and duodenal digesta samples were ashed at $550{ }^{\circ} \mathrm{C}$ for $12 \mathrm{~h}$. All digests were taken up for subsequent analysis in $5 \%(\mathrm{v} / \mathrm{v})$ $\mathrm{HCl}$. Magnesium in these samples and in urine, plasma and rumen and duodenal supernatant fractions was determined by atomic absorption spectrophotometry following dilution in $0 \cdot 1 \mathrm{M} \mathrm{HCl}$ containing $2000 \mathrm{ppm}$ strontium. Sodium and potassium in feed, plasma and urine were determined by flame emission spectrophotometry after dilution in a 1000 ppm lithium carbonate solution.

Magnesium solubility was calculated as the proportion of total digesta $\mathrm{Mg}$ present in the $30000 \mathrm{~g}$ supernatant fraction.

\section{Statistical analysis}

For ruminal and duodenal flow measurements, the balance period was the last 4 days of the infusion period, whereas for urinary and faecal excretion measurements the balance period was the last 8 days of the infusion period. The basic analysis is that for a split plot of the four $\mathrm{K}$ treatments. Within each $\mathrm{K}$ treatment there were four animals assigned to each of four $\mathrm{Mg}$ treatments (16 animals in total) and these four $\mathrm{Mg}$ treatments were repeated over four periods in a 'round robin' manner according to a Latin square design balanced for carry-over effects. Orthogonal polynomials were used to establish if any of the $\mathrm{K}$ treatments affected the variates in a non-linear manner. Data for urinary and faecal $\mathrm{Mg}$ excretion, plasma $\mathrm{Mg}$ concentration and digesta $\mathrm{pH}$ were analysed in a balanced Latin square for main effects ( $\mathrm{K}$ and $\mathrm{Mg}$ ) and interactions. Data for duodenal $\mathrm{Mg}$ flow, rumen $\mathrm{Mg}$ solubility and $\mathrm{Mg}$ concentration in rumen whole digesta and supernatant were analysed in an incomplete Latin square as these measurements were available only for three periods. Both analyses used the ANOvA procedure of GENSTAT 5, Release 2.2 (Lawes Agricultural Trust 1991) to calculate estimated treatment means. 


\section{RESULTS}

The concentrate diet and lucerne hay contained 890 and $920 \mathrm{~g} \mathrm{DM} / \mathrm{kg}$ fresh weight, respectively, and the ration fed had an apparent DM digestibility of $0 \cdot 72$. Individual sheep mean, within-period DM intake ranged from 830 to $893 \mathrm{~g} /$ day and was unaffected by treatment. Mineral concentrations in the two feeds are presented in Table 1. Mean dietary $\mathrm{Mg}, \mathrm{Na}$ and $\mathrm{K}$ intakes were $1.3,0.76$ and $15.0 \mathrm{~g} /$ day, respectively.

\section{Potassium and magnesium infusion rates}

The four $\mathrm{K}$ treatments provided total daily $\mathrm{K}$ supplies of $15,24,33$ and $42 \mathrm{~g} /$ day, or the equivalent of 16,26 , 36 and $46 \mathrm{~g} \mathrm{~K} / \mathrm{kg} \mathrm{DM}$ for $\mathrm{K}$ treatments $1-4$, respectively.

Magnesium infusions supplied between 0 and $1.86 \mathrm{~g} \mathrm{Mg}$ /day which resulted in total daily $\mathrm{Mg}$ supplies of $1 \cdot 3,1 \cdot 8,2 \cdot 3$ and $3 \cdot 1 \mathrm{~g} /$ day, or the equivalent of $1 \cdot 5,2 \cdot 0,2 \cdot 5$ and $3 \cdot 5 \mathrm{~g} \mathrm{Mg} / \mathrm{kg} \mathrm{DM}$ for $\mathrm{Mg}$ treatments $1-4$, respectively.

Table 1. Dry matter (DM; g/day) intake and mineral concentration $(\mathrm{g} / \mathrm{kg} \mathrm{DM})$ of the concentrate diet and lucerne hay

\begin{tabular}{lrrrrrr}
\hline \hline & \multicolumn{5}{c}{ Mineral concentration } \\
\cline { 3 - 7 } & Intake & $\mathrm{Mg}$ & $\mathrm{K}$ & $\mathrm{Na}$ & $\mathrm{Ca}$ & $\mathrm{P}$ \\
\hline Concentrate & 801 & 1.35 & 12.14 & 0.91 & 5.57 & 2.68 \\
Lucerne hay & 92 & 2.32 & 57.56 & 0.29 & 9.95 & 2.67 \\
\hline \hline
\end{tabular}

\section{Main treatment effects}

There were significant effects of $\mathrm{K}$ treatment on four of the eight variable means, viz. a reduction in urinary $\mathrm{Mg}$ excretion $(P<0.001)$ and plasma $\mathrm{Mg}$ concentration $(P<0.001)$ and an increase in duodenal $\mathrm{Mg}$ flow $(P<0.05)$ and rumen digesta $\mathrm{pH}(P<0.05)$. There was no effect of $\mathrm{K}$ on faecal $\mathrm{Mg}$ excretion, rumen $\mathrm{Mg}$ solubility or $\mathrm{Mg}$ concentration in either rumen supernatant or whole digesta.

Magnesium treatment, however, had significant effects $(P=0.001$ or below) on all variable means except digesta $\mathrm{pH}$ and rumen $\mathrm{Mg}$ solubility.

\section{Urinary magnesium excretion}

A significant linear relationship $(P<0.001)$ was observed between the rate of $\mathrm{Mg}$ intake and urinary $\mathrm{Mg}$ excretion (Table 2). Increasing the $\mathrm{K}$ supply from 16 to $46 \mathrm{~g} / \mathrm{kg}$ DM reduced urinary $\mathrm{Mg}$ excretion $(P<0.001)$ linearly across all $\mathrm{Mg}$ treatments (Table 2). In absolute terms the reduction in urinary $\mathrm{Mg}$ excretion was similar for all $\mathrm{K}$ infusion rates. However, as a proportion of total urinary excretion, the reduction was greatest at low $\mathrm{Mg}$ supplies.

\section{Urinary potassium excretion}

A significant linear increase in mean urinary $\mathrm{K}$ excretion $(P<0.001)$ was observed as $\mathrm{K}$ supply increased. Mean urinary $\mathrm{K}$ excretion values ranged from 5.8 for $\mathrm{K} 1$ to $25.4 \mathrm{~g} /$ day for $\mathrm{K} 4$ (s.E. 0.68 ).

Table 2. Effect of potassium $(K)$ and magnesium $(M g)$ infusion on mean urinary and faecal magnesium excretion $(\mathrm{g} /$ day), plasma magnesium concentration $(\mathrm{mmol} / \mathrm{l})$ and duodenal magnesium flow $(\mathrm{g} /$ day) during the balance period

\begin{tabular}{|c|c|c|c|c|}
\hline \multirow[b]{2}{*}{ Treatment } & \multirow{2}{*}{$\frac{\text { Urinary } \mathrm{Mg}}{(\mathrm{g} / \text { day })}$} & \multirow{2}{*}{$\frac{\text { Faecal Mg }}{\text { (g/day) }}$} & \multirow{2}{*}{$\frac{\text { Plasma Mg }}{(\mathrm{mmol} / \mathrm{l})}$} & \multirow{2}{*}{$\begin{array}{c}\begin{array}{c}\text { Duodenal } \mathrm{Mg} \\
\text { flow }\end{array} \\
\text { (g/day) }\end{array}$} \\
\hline & & & & \\
\hline K1 & $0 \cdot 61$ & 1.34 & 0.94 & 1.65 \\
\hline K2 & 0.55 & 1.38 & $0 \cdot 87$ & 1.86 \\
\hline K3 & 0.47 & 1.47 & $0 \cdot 81$ & $2 \cdot 08$ \\
\hline K4 & $0 \cdot 42$ & $1 \cdot 43$ & $0 \cdot 79$ & $2 \cdot 02$ \\
\hline S.E. & $0 \cdot 022$ & 0.094 & 0.023 & $0 \cdot 110$ \\
\hline D.F. & 12 & 12 & 12 & 8 \\
\hline $\mathrm{Mg} 1$ & $0 \cdot 28$ & $0 \cdot 85$ & $0 \cdot 81$ & $1 \cdot 17$ \\
\hline $\mathrm{Mg} 2$ & $0 \cdot 42$ & $1 \cdot 18$ & 0.84 & 1.52 \\
\hline Mg3 & $0 \cdot 60$ & 1.45 & $0 \cdot 88$ & $2 \cdot 04$ \\
\hline $\mathrm{Mg} 4$ & $0 \cdot 74$ & $2 \cdot 14$ & $0 \cdot 88$ & $2 \cdot 88$ \\
\hline S.E. & 0.030 & $0 \cdot 069$ & $0 \cdot 014$ & 0.052 \\
\hline D.F. & 24 & 24 & 24 & 12 \\
\hline
\end{tabular}


Table 3. Effect of potassium and magnesium infusion on rumen digesta $\mathrm{pH}$, rumen $\mathrm{Mg}$ solubility and rumen whole digesta and supernatant $\mathrm{Mg}$ concentration

\begin{tabular}{|c|c|c|c|c|}
\hline & & $\begin{array}{l}\text { Rumen Mg } \\
\text { solubility }\end{array}$ & $\begin{array}{l}\mathrm{Mg} \text { concentration } \\
\text { whole rumen } \\
\text { digesta }\end{array}$ & $\begin{array}{l}\mathrm{Mg} \text { concentration } \\
\text { in supernatant }\end{array}$ \\
\hline Treatment & Digesta $\mathrm{pH}$ & $(\%)$ & $(\mathrm{mg} / 100 \mathrm{~g} \mathrm{DM})$ & $(\mathrm{mg} / 100 \mathrm{ml})$ \\
\hline $\mathrm{K} 1$ & $5 \cdot 83$ & 37 & 224 & $26 \cdot 8$ \\
\hline $\mathrm{K} 2$ & $5 \cdot 71$ & 35 & 246 & $27 \cdot 8$ \\
\hline K3 & $6 \cdot 02$ & 34 & 256 & $24 \cdot 8$ \\
\hline K4 & 5.91 & 33 & 265 & $23 \cdot 7$ \\
\hline S.E. & 0.085 & $5 \cdot 3$ & $14 \cdot 3$ & $3 \cdot 55$ \\
\hline D.F. & 12 & 8 & 8 & 8 \\
\hline Mg1 & $5 \cdot 88$ & 34 & 162 & 19 \\
\hline $\mathrm{Mg} 2$ & $5 \cdot 85$ & 33 & 211 & 21 \\
\hline Mg3 & $5 \cdot 90$ & 36 & 264 & 26 \\
\hline Mg4 & $5 \cdot 84$ & 36 & 353 & 37 \\
\hline S.E. & $0 \cdot 044$ & 1.4 & $8 \cdot 1$ & $1 \cdot 2$ \\
\hline D.F. & 24 & 12 & 12 & 12 \\
\hline
\end{tabular}

Overall, urinary $\mathrm{K}$ excretion values, irrespective of Mg supply, represented 38, 55, 58 and $60 \%$ of total daily K supply for K treatments $1-4$, respectively. Magnesium supply had no significant effect $(P>0.05)$ on urinary $\mathrm{K}$ excretion.

\section{Faecal magnesium excretion}

Mean faecal $\mathrm{Mg}$ excretion was positively linearly related to $\operatorname{Mg}(P<0.001)$ but not $\mathrm{K}(P>0.05)$ supply (Table 2). However, a significant carry-over effect was observed, which was still present in further analysis when the data were pooled over the last 3 days of the balance period.

\section{Plasma magnesium}

Significant positive linear relationships $(P=0.001)$ were observed between $\mathrm{Mg}$ supply and plasma $\mathrm{Mg}$ concentration and linear negative relationships $(P<$ $0 \cdot 001$ ) with K supply (Table 2 ). In general, the effect of $\mathrm{K}$ in depressing plasma $\mathrm{Mg}$ concentration was least at the lowest rate of supply of $\mathrm{Mg}$, although the effects of high $\mathrm{K}$ and low $\mathrm{Mg}$ supply on plasma $\mathrm{Mg}$ were independent but additive in effect.

\section{Plasma potassium}

A significant $(P<0 \cdot 01)$ linear increase in plasma $\mathrm{K}$ concentration was observed as $\mathrm{K}$ supply increased from 16 to $46 \mathrm{~g} / \mathrm{kg} \mathrm{DM}$ on all $\mathrm{Mg}$ treatments. Mean plasma $\mathrm{K}$ concentration was $4.35( \pm 0.058)$ and 4.73 $( \pm 0.063) \mathrm{mmol} / \mathrm{l}$ for $\mathrm{K} 1$ and $\mathrm{K} 4$, respectively. Magnesium supply had no significant effect on plasma $\mathrm{K}$ concentration.

\section{Rumen digesta}

There was no effect of $\mathrm{Mg}$ supply on rumen $\mathrm{pH}$ or $\mathrm{Mg}$ solubility in rumen digesta and the data have been combined within $\mathrm{K}$ treatments and are given in Table 3. There was a significant cubic effect of $\mathrm{K}$ supply on digesta $\mathrm{pH}(P<0.05)$, with the two highest $\mathrm{K}$ treatments having the highest $\mathrm{pH}$. The concentration of $\mathrm{Mg}$ in whole rumen contents increased linearly with increase in $\mathrm{Mg}$ supply $(P<0.001)$ but not with an increase in $\mathrm{K}$ supply $(P>0 \cdot 05)$. Magnesium concentration in the supernatant fraction of rumen digesta increased with increase in $\mathrm{Mg}$ supply $(P<$ $0 \cdot 001$ ), and tended to decrease with increase in $\mathrm{K}$ supply.

\section{Duodenal digesta flow}

Duodenal digesta flow increased $(P<0.005)$ with increasing $\mathrm{K}$ supply from $10 \cdot 2$ during $\mathrm{K}$ treatment 1 to 12.3 litres/day during $\mathrm{K}$ treatment 4 (s.E. $0 \cdot 46$ ) and was associated with a non-significant increase in rumen volume from $3 \cdot 1$ to 3.7 litres for $\mathrm{K}$ treatments 1 and 4, respectively. There was a tendency for digesta flow rate to increase with $\mathrm{Mg}$ supply, but this increase was not significant.

The flow of $\mathrm{Mg}$ in whole duodenal digesta (Table 2) increased linearly with both $\mathrm{K}(P<0.05)$ and $\mathrm{Mg}(P$ $<0.001)$ supply, although the effect of $\mathrm{Mg}$ was greater than that of $\mathrm{K}$.

\section{DISCUSSION}

The amount of $\mathrm{Mg}$ disappearing before the duodenum at the low $\mathrm{K}$ intake increased with increasing $\mathrm{Mg}$ supply, as would be expected from the work of Martens et al. (1978) and McLean et al. (1984) which 


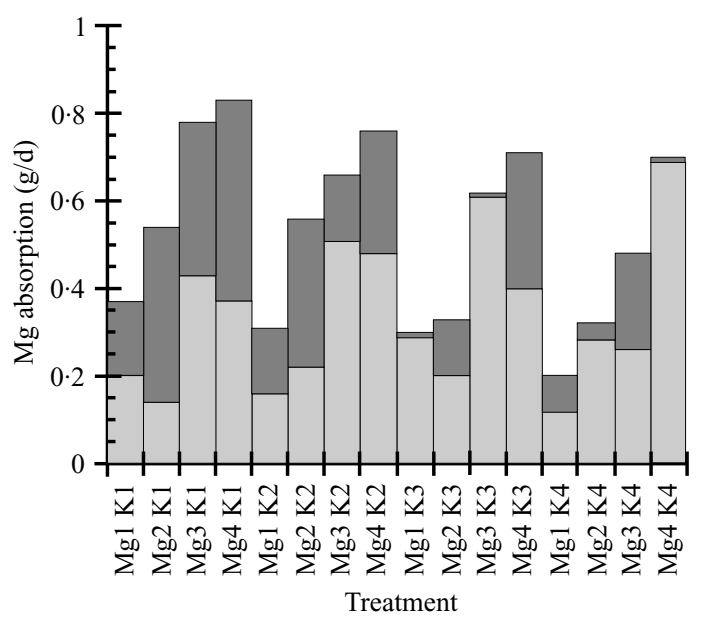

Fig. 1. Effect of potassium and magnesium infusions on the partitioning of magnesium absorption between the rumen ( $\square)$ and a post-ruminal site (圓).

showed a direct relationship between rumen $\mathrm{Mg}$ concentration and rate of $\mathrm{Mg}$ absorption. In addition, at this level of $\mathrm{K}$ supply the rumen appeared to be the major site of $\mathrm{Mg}$ absorption, as would be anticipated from the studies of Grace \& MacRae (1972), Tomas \& Potter (1976b) and Field \& Munro (1977). The increase in duodenal $\mathrm{Mg}$ flow with increasing $\mathrm{K}$ supply (Table 2) further confirms the findings of Tomas \& Potter $(1976 c)$ which have demonstrated impairment of $\mathrm{Mg}$ absorption from the rumen with increasing rumen fluid $\mathrm{K}$ concentration.

A significant finding, however, was that despite negligible absorption of $\mathrm{Mg}$ from the rumen at high $\mathrm{K}$ supply, between 0.2 and $0.7 \mathrm{~g} /$ day of $\mathrm{Mg}$ was excreted in urine. This must suggest that compensatory absorption was occurring from some site distal to the rumen (Fig. 1) particularly since this could not be furnished by the depression in plasma concentration and skeletal $\mathrm{Mg}$ cannot be rapidly mobilized in mature sheep (Terashima et al. 1987). The data in Fig. 1 clearly show that not only was less $\mathrm{Mg}$ absorbed from the entire digestive tract as $\mathrm{K}$ supply increased but the site of net absorption also changed, the amount absorbed from the hindgut increasing significantly. Tomas \& Potter (1976b) showed the large intestine to be capable of absorption of substantial quantities of $\mathrm{Mg}$ when $\mathrm{Mg}$ was supplied by infusion into the ileum rather than the rumen and McLean et al. (1984) showed that with increasing rate of $\mathrm{Mg}$ infusion increasing proportions of the $\mathrm{Mg}$ absorbed were absorbed distal to the pylorus. Furthermore, Grace \& MacRae (1972) observed that while only $2 \%$ of net $\mathrm{Mg}$ absorption occurred distal to the pylorus in continuously fed sheep, $50 \%$ was absorbed at this site in sheep fed once daily, which they interpreted as resulting from a pulse of $\mathrm{Mg}$ which overloaded the rumen capacity for transport and became available for absorption distally. The present work suggests that distal sites become more important in $\mathrm{K}$ induced reduction in absorption from the rumen (Fig. 1) and could well be the sites from which orally administered $\mathrm{Mg}$ supplements are absorbed. Interestingly, Robson et al. (1997) found it necessary to assume hindgut absorption of $\mathrm{Mg}$ in order to satisfactorily explain experimental observations from balance trials in the development of a computer simulation model of $\mathrm{Mg}$ absorption.

The distal site of $\mathrm{Mg}$ absorption in the present experiment is most likely to be the large intestine, as net secretion of $\mathrm{Mg}$ from the small intestine has been reported in many experiments (Ben-Ghedalia et al. 1975; Tomas \& Potter 1976a; Bown et al. 1989) and there are several reports of net $\mathrm{Mg}$ absorption from the large intestine (Tomas \& Potter 1976 $a$; McLean et al. 1984; Dalley \& Sykes 1989). Little is known, however, about the mechanism of absorption from the hindgut. The increase in $\mathrm{Mg}$ absorption from the large intestine observed by Tomas \& Potter (1976b) was associated with a 20-25\% increase in $\mathrm{Mg}$ entering the large intestine, and in the present work a greater $\mathrm{Mg}$ flow and concentration was probably responsible for the observed increase in $\mathrm{Mg}$ absorption. Although McLean et al. (1984) demonstrated a much lower potential difference between the duodenum and plasma than between rumen and plasma (13.30 and $36.67 \mathrm{mV}$, respectively), which would facilitate diffusional transport, nothing is known about conditions and transport mechanisms in the hindgut. Clearly it is either not subject to the same depression by digesta $\mathrm{K}$ concentration or $\mathrm{K}$ concentration in that part of the tract is not significantly affected by $\mathrm{K}$ intake. The former might be the more likely since we had indirect evidence, in urinary $\mathrm{K}$ excretion, that $\mathrm{K}$ content in hindgut digesta would have increased with $\mathrm{K}$ supplementation.

The effect of $\mathrm{K}$ and $\mathrm{Mg}$ on retention of $\mathrm{Mg}$ in the body was estimated by multiplying plasma $\mathrm{Mg}$ concentration by the estimated volume of the extracellular fluid (ECF) pool (0.15 × weight; Storry 1961), assuming ECF $\mathrm{Mg}$ was in equilibrium with plasma $\mathrm{Mg}$. Despite significant increases in plasma $\mathrm{Mg}$ concentration with increasing $\mathrm{Mg}$ supply and decreases with increasing $\mathrm{K}$ supply, actual quantities of $\mathrm{Mg}$ amounted to only $0 \cdot 1-0 \cdot 3 \mathrm{~g}$, indicating that retention of $\mathrm{Mg}$ was small relative to daily throughput of $\mathrm{Mg}$.

Coefficients of absorption for $\mathrm{Mg}$ ranged from $0 \cdot 13$ at low $\mathrm{Mg}$ and high $\mathrm{K}$ intakes to 0.35 at high $\mathrm{Mg}$ and low $\mathrm{K}$ intakes and span the range anticipated in mature ruminants (ARC 1980). The very low coefficient of absorption observed at high $\mathrm{K}$ supplies when combined with a low Mg supply was less than the conservative value of 0.17 used in most calculations of $\mathrm{Mg}$ requirement (ARC 1980). The K concentrations 
used in the present work (16-46 $\mathrm{g} \mathrm{K} / \mathrm{kg} \mathrm{DM})$ represent the range experienced by pastoral ruminants. It may be that the magnitude of the depression in net $\mathrm{Mg}$ absorption at high $\mathrm{K}$ and low $\mathrm{Mg}$ intake is greater than previously thought.

The decrease in $\mathrm{Mg}$ absorption from the rumen with increasing $\mathrm{K}$ supply was associated with a small increase in rumen digesta $\mathrm{pH}$ which depressed $\mathrm{Mg}$ concentrations in the liquid phase of digesta. Smith \& Horn (1976) demonstrated in vitro, using rumen fluid, a decline in $\mathrm{Mg}$ solubility with increasing $\mathrm{pH}$, the critical $\mathrm{pH}$ for change in solubility being 6.5-7.0. Although rumen digesta $\mathrm{pH}$ at the low $\mathrm{K}$ supply in the present experiment was $c .5 \cdot 8$, at high $\mathrm{K}$ supplies it increased to 6.0 and was associated with a decline in $\mathrm{Mg}$ solubility from $c .0 \cdot 37$ to $0 \cdot 33$. The greatest effect of $\mathrm{K}$ supply on $\mathrm{Mg}$ solubility was observed at low $\mathrm{Mg}$ supply where it was 0.42 and 0.29 on treatments with $\mathrm{K} 1$ and K4, respectively. Similar effects of $\mathrm{K}$ were observed by Greene et al. (1983c) and Wylie et al. (1985), although these workers used potassium bicarbonate as the $\mathrm{K}$ source and change in $\mathrm{pH}$ may have been due to the increase in bicarbonate ion concentration.

We gratefully acknowledge the assistance of $\mathbf{J}$. R. Sedcole and the referees in the enhancement of the clarity of this paper.

\section{REFERENCES}

Agricultural Research Council (1980). The Nutrient Requirements of Ruminant Livestock. Slough: Commonwealth Agricultural Bureaux.

Ben-Ghedalia, D., Tagari, H., Zamwel, S. \& Bondi, A. (1975). Solubility and net exchange of calcium, magnesium and phosphorus in digesta flowing along the gut of the sheep. British Journal of Nutrition 33, 87-94.

Bown, M. D., Poppi, D. P. \& Sykes, A. R. (1989). The effects of concurrent infection of Trichostrongylus colubriformis and Ostertagia circumcincta on calcium, phosphorus and magnesium transactions along the digestive tract of lambs. Journal of Comparative Pathology 101, 11-20.

Dalley, D. E. \& Sykes, A. R. (1989). Magnesium absorption from the large intestine of sheep. Proceedings of the New Zealand Society of Animal Production 49, 229-232.

Downes, A. M. \& MCDonald, I. W. (1964). The chromium51 complex of ethylenediamine tetraacetic acid as a soluble rumen marker. British Journal of Nutrition 18, 153-162.

FaICHNEY, G. J. (1975). The use of markers to partition digestion within the gastro-intestinal tract of ruminants. In Digestion and Metabolism in the Ruminant (Eds I. W. McDonald \& A. C. I. Warner), pp. 277-291. Armidale, NSW, Australia: University of New England Publishing Unit.

Field, A. C. \& Munro, C. S. (1977). The effect of site and quantity on the extent of absorption of $\mathrm{Mg}$ infused into the gastro-intestinal tract of sheep. Journal of Agricultural Science, Cambridge 89, 365-371.

Field, A. C. \& SutTLE, N. F. (1979). Effect of high potassium and low magnesium intakes on the mineral metabolism of monozygotic twin cows. Journal of Comparative Pathology 89, 431-439.

Gabel, G. \& Martens, H. (1985). Magnesium absorption from the rumen of heifers. Zentralblatt fur Veterinärmedizin Reihe A 32, 636-639.

Grace, N. D. \& MacRae, J. C. (1972). Influence of feeding regimen and protein supplementation on the sites of net absorption of magnesium in sheep. British Journal of Nutrition 27, 51-55.

Greene, L. W., Fontenot, J. P. \& Webb, K. E., JR (1983a). Effect of dietary potassium on absorption of magnesium and other macroelements in sheep fed different levels of magnesium. Journal of Animal Science 56, 1208-1213.

Greene, L. W., Webb, K. E., Jr \& Fontenot, J. P. (1983b).
Effect of potassium level on site of absorption of magnesium and other macroelements in sheep. Journal of Animal Science 56, 1214-1221.

Greene, L. W., Fontenot, J. P. \& Webb, K. E., JR (1983 c). Site of magnesium and other macromineral absorption in steers fed high levels of potassium. Journal of Animal Science 57, 503-510.

Hecker, J. F. (1974). Experimental Surgery on Small Ruminants. London: Butterworths.

Lawes Agricultural Trust (1991). Genstat 5, Release 2.2, Reference Manual. Oxford: Clarendon Press.

Martens, H. \& Blume, I. (1986). Effect of intraruminal sodium and potassium concentrations and of the transmural potential difference on magnesium absorption from the temporarily isolated rumen of sheep. Quarterly Journal of Experimental Physiology 71, 409-415.

Martens, H., Harmeyer, J. \& Michael, H. (1978). Magnesium transport by the isolated rumen epithelium of sheep. Research in Veterinary Science 24, 161-168.

McLean, A. F., Buchan, W. \& Scott, D. (1984). Magnesium absorption in mature ewes infused intraruminally with magnesium chloride. British Journal of Nutrition 52, 523-527.

Newton, G. L., Fontenot, J. P., Tucker, R. E. \& Polan, C. E. (1972). Effects of high dietary potassium intake on the metabolism of magnesium by sheep. Journal of Animal Science 35, 440-445.

Robson, A. B. (1991). Modelling of magnesium metabolism in ruminants. PhD thesis, Lincoln University, New Zealand.

Robson, A. B., Field, A. C., Sykes, A. R. \& McKinnon, A. E. (1997). A model of magnesium metabolism in young sheep. $\mathrm{Mg}$ absorption and excretion. British Journal of Nutrition.

SMith, R. H. \& HoRn, J. P. (1976). Absorption of magnesium, labelled with magnesium-28, from the stomach of the young steer. In International Symposium on Nuclear Techniques in Animal Production and Health, pp. 253-260. Vienna: International Atomic Energy Agency.

Storry, J. E. (1961). Calcium and magnesium contents of various secretions entering the digestive tract of sheep. Nature 190, 1197-1198.

Terashima, Y., Matsunobu, S., Yanagisawa, Y. \& Itoh, H. (1987). Calcium mobilization in hypomagnasemic wethers fed on a low magnesium and/or high potassium diet. Japanese Journal of Zootechnical Sciences 59, 75-81. 
Thompson, T. H. \& Blanchrlower, W. J. (1971). Wet ashing apparatus to prepare biological materials for atomic absorption spectrophotometry. Laboratory Practice 20, 859-861.

Tomas, F. M. \& PotTer, B. J. (1976a). The site of magnesium absorption from the ruminant stomach. British Journal of Nutrition 36, 37-45.

Tomas, F. M. \& PotTER, B. J. (1976b). Interaction between sites of magnesium absorption in the digestive tract of the sheep. Australian Journal of Agricultural Research 27, 437-446.

Tomas, F. M. \& PotTer, B. J. (1976c). The effect and site of action of potassium upon magnesium absorption in sheep. Australian Journal of Agricultural Research 27, 873-880.

Wylie, M. J., Fontenot, J. P. \& Greene, L. W. (1985) Absorption of magnesium and other macrominerals in sheep infused with potassium in different parts of the digestive tract. Journal of Animal Science 61, 1219-1229. 